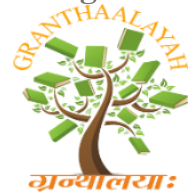

INTERNATIONAL JOURNAL OF RESEARCH GRANTHAALAYAH A knowledge Repository

Science

\title{
THE ECO-FRIENDLY BAGH PRINTING
}

\author{
Dr. Sadhana Chouhan ${ }^{1}$, Sunita Patil ${ }^{2}$ \\ ${ }^{1}$ HOD (Drawing \&Painting), Maharajabhoj Government P.G. College Dhar, (M. P.), India \\ ${ }^{2}$ PHD Research Scholar
}

\begin{abstract}
Bagh, which lends its name to the Bagh prints, is a small tribal village/ town in the Kukshi tehsil of Dhar district of Madhya Pradesh. Legend has it that the village of Bagh, the Bagh River, and the nearby Bagh caves (3rd \& 5th century AD, with rich carvings and paintings dedicated to both Hindu as well as Buddhist deities) got their name from the baghs or tigers that inhabited the region. The village, located on the Dhar-Kukshi road, has a population of about 12,000. The Bagh River flows at a distance of about a kilometer from the Dhar-Kukshi road. From a near forgotten tribal art in a small village in Dhar district of Madhya Pradesh, today Bagh prints have left an imprint in the textile and art world.
\end{abstract}

Keywords: Bagh Print; Natural Colour.

Cite This Article: Dr. Sadhana Chouhan, and Sunita Patil. (2019). “THE ECO-FRIENDLY BAGH PRINTING." International Journal of Research - Granthaalayah, 7(11SE), 104-110. https://doi.org/10.5281/zenodo.3585086.

\section{Introduction}

Originally used only on lehengas and ghagras, today the prints adorn saris, dress materials and bed covers. Umar Farukh speaks about the unique block print, its history, the processes involved and its soaring popularity. Ismail Suleiman moved to Bagh village in the 1950s and began practising and giving new dimensions to the block printing. The art was already being practised by 80 per cent of the Adivasi population. In the 1960s, due to the lure of synthetics, many artisans left the craft but stuck to vocation and began to redefine its concept, process and look. He got 200 and 300 -year-old blocks based on traditional motifs inspired by the 1,500-year-old paintings found in caves in the region. These motifs include chameli or jasmine, maithir or mushroom, leheriya and jurvaria or small dots on the field.

\section{Bagh Print: The Procedure}

The procedure for Bagh Printing is painstaking. Blocks are made in seasoned wood. Designs are engraved and carved. The blocks are of two types Rek and Gad. Each block takes two to five days to be made with eight hours of work put in daily. Generally, the printing is done on cotton. It is 
first soaked in water for about twelve hours and then suckled with legs. It is then bleached and washed in "Sanchorapaani". The Harda powder obtained from a type of tree is mixed in water and the fabric is washed in it for about five minutes. It is then dried in sun. For printing, Ferrous Sulphate or slum is first mixed with water. A paste using tamarind seed powder is made. The fabric to be printed upon is spread upon a table. Blocks are carefully chosen and then printing begins. Gad is used first to create bold defining forms. Then the designs are detailed out with rek block. The next process is the washing of printed bundles in running water and then beaten against stones. It is then left to dry in the sun. Once the fabric is dried it is taken to a huge copper vessal for boiling. It contains about hundred grams of alizarin and two hundred liters of water. Dhardikphool are added to lend shine to the print and prevent froth from damaging the fabric. Bleaching is done once again after boiling to remove stains and colours that have bled. One final wash in clean water is done and the printed fabric is laid out in sun to dry.

\section{Ecofriendly Process Bagh Printing}

Process Hand block printing comprises of an intricate but interesting process. Work is divided amongst the craftsmen. The nature of work at the workshop is different from that at the riverside. The work at the riverside is less complicated but requires more energy and stamina. The labor in the workshop is expected to be more skillful, diligent and patient, since block printing requires a stable hand and the capacity to sit and work for hours together. Each one specializes in the task he is doing.

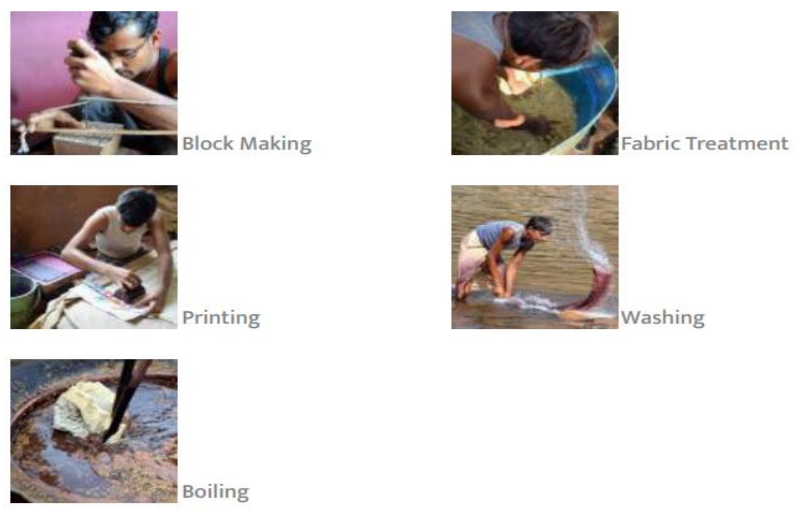

Figure 1: Production Process

\section{Production Process}

Hand block prints are developed by natural colors. Bagh print leads India in the entire world. Bagh layouts are dramatic in the use of black and red alternately on a white background. The black colour is prepared with ferrous sulphate mixed with tamarind seed powder and glue which is cooked in water and stored for use. Each sari takes a minimum of three weeks to complete after the design is printed. During this period, it is washed at least three times and sent to the bhatti/ oven at least twice. Two persons stand knee deep in water to wash the fabric so that superfluous colour is removed. The fabric / sari is boiled in a cauldron of water on a bhatti with regulated heat for the colour to emerge. This is extremely painstaking. The fabric used originally was cotton, though now saw tassar, crepe, and silk are being used with excellent results. Every process used is manual and though the techniques and designs are age-old they have a contemporary appeal. Bagh 
[Chouhan et. al., Vol.7 (Iss.11SE): November 2019] चित्रकला और उसके अंतः अनुशासनिक सम्बन्ध

Painting and Its Interdisciplinary Relation
ISSN- 2350-0530(O), ISSN- 2394-3629(P) Index Copernicus Value (ICV 2018): 86.20

DOI: 10.5281/zenodo.3585086

prints are known for their fine quality printing and bright vegetables colors and may be recognized by their geometric repetitive patterns in different variations and colors that are mainly red and black block printed predominantly on white base. Khaki and mustard vegetables colors are used for dyeing the fabric after printing. The block designs that have managed to survive with time are nearly 200 years old and are still being used; some of them are 100 to 50 years old and on printing still find a market for themselves. New additions are done every six months as per market demand and feel. At the same time care is taken to see that this new design is a new variation of the old one. Some old blocks and their names that are being still used are

(i)Nandana, (ii) Laheriya, (iii) Attha, (iv) Nandanakimirache, (v) Nandanakabutta, (vi) Aabotchabutta, (vii) Khedekabodh, (viii) Indoribodh, (ix) Indorisaaj, (x) Indoriaddya, (xi) Ahmedabadisaaj, (xii) Makhi, (xiii) Palliwalizanjira, (xiv) Zanjiri, (xv) Jodhpuri, (xvi) Jawareya, (xvii) Molya border, (xviii) Molyabodh, (xix) Khiralakaire, (xx) Mungphali, (xxi) Chaukada, (xxii) Nareyal, (xxiii) Teekoni and (xxiv) Thuddi

\section{Raw Materials}

The main raw material for the products is fabric which most commonly of cotton fibre. Sometimes Maheshwari suit material, kosa silk, bamboo chicks and cotton durries are worked on only on order and Chiffon, crepe, georgette tissue and mulberry silk are worked on occasionally. Apart from this, the wooden blocks are used to emboss the desired designs on the fabric. Generally, these blocks are sourced from Pethapur, Gandhinagar and Jaipur. The specification of the cotton fabric is given below:

\begin{tabular}{|c|l|l|l|}
\hline S. No & Fabric & Specification & Final product \\
\hline 1 & $\begin{array}{l}\text { Cotton } \\
\text { Mulmul }\end{array}$ & $\begin{array}{l}100 \times 120 \text { s count } \\
\text { and } 92 \times 80 \text { picks }\end{array}$ & $\begin{array}{l}\text { Saris, Dupattas and } \\
\text { Salwar Suits }\end{array}$ \\
\hline 2 & $\begin{array}{l}\text { Cotton } \\
\text { Cambric }\end{array}$ & $\begin{array}{l}40 \times 40 \text { s count } \\
\text { and } 92 \times 80 \\
\text { picks. }\end{array}$ & Dress material \\
\hline 3 & $\begin{array}{l}\text { Yardage } \\
\text { fabric }\end{array}$ & 20x20s count & $\begin{array}{l}\text { Bedcovers/Bed } \\
\text { sheets }\end{array}$ \\
\hline
\end{tabular}

The cloth - mainly cotton and sometimes silk - is usually bought from the market. The fabric used by the Khatris may be Bangalori silk (bought from Indore), cotton or grey latha (bought from Indore and Bombay) or silk-cotton mix (bought from Maheshwariin Khargoan district). Silk needs much more delicate handling and care; generally, a silk cloth takes almost double the time for its completion than does a piece of cotton cloth the same size. Other ingredients such as Cenchura (raw salt), aarandikatel (castor oil), grounded goat's dung, Fitkari (alum), Hirakasish or iron sulphate, jaggery, Pomegranate skins, indigo leaves, lime, Sajji, Leaves of Dhavdi, sanchara (rock salt), mengni, Iron sulphate, chiyan (tamarind seed) powder, dhavdakaphool (for shining and fixing) and alizarine (to fasten colours), etc are used in the various processes of printing.

\section{- Pre-Printing Activities}

\section{Khara Karna}

The cloth is taken to the river where it is thoroughly washed. 100 single sheets are washed at one time - that is, 250 cuts of fabric 60" wide. The fabric is soaked in water for 2 hours. It is washed 
[Chouhan et. al., Vol.7 (Iss.11SE): November 2019]

चित्रकला और उसके अंतः अनुशासनिक सम्बन्ध

Painting and Its Interdisciplinary Relation

by beating it on riverside stones several times. It is brought back to the workshop after drying. The fabric is soaked for just over an hour, and then beaten on a stone slab to remove the starch, before being washed in clean water and dried.

\section{MengniKarna}

The cloth is brought back to the workshop, and dipped in a particular solution for an entire night, after which it is put out to dry by spreading on a floor of stones out in a verandah. This involves three items:

1) solution of $3 \mathrm{~kg}$ of sanchara (rock salt) soaked in 15 litres of water, stirred till it melts.

2) $10 \mathrm{~kg}$ of mengni soaked in 10-15 litres of water. When it is soft, it is made into a paste by grinding it with a brick on a stone surface.

3) $1 \mathrm{~kg}$ of arandikatel or unrefined castor oil.

The three are mixed to make a dhaul solution. The fabric is immersed in this water - it is to be kept under water for the whole night. The fabric is then taken to the river and washed in flowing water. Then it is dried. This process has to be repeated three times; each time the fabric has to be kept in the water for 10 to 15 minutes. By this time the material becomes quite soft. It is cut into manageable pieces. For 1,000 cuts of fabric, the quantities of ingredients required are: a. $4 \mathrm{~kg}$ of sanchara soaked in 10 litres of water and made into a paste. b. $10 \mathrm{~kg}$ of mengni, soaked in 15-20 litres of water, softened, ground on a stone slab with a brick and made into a paste. c. $2 \mathrm{~kg}$ of arandika tel. The arandikatel is mixed with the sanchara and stirred till it curdles and turns into a paste. The paste made out of mengni is then mixed with the solution. All this is mixed with water till there is about 50 litres of the mixture in the vat. The fabric is soaked in this water till it is completely wet several times over. Its then kept in the vat and pressed hard by several men - with their feet - for about half an hour till it softens.

\section{Treating with Harara}

Treating the cloth with harara gives an off-white or off-yellow background to the cloth and also aids in strengthening the tones of the black and red colours that are printed later. On the day after mengnikarna the fabric has to be treated with a solution of harara powder (the alternative, bahera is not used because it gives a blackish tinge to the fabric). About $10 \mathrm{~kg}$ of harara powder is soaked in 25 litres of water for half an hour. Then about 20 litres of plain water is mixed with 10 mugs of harara-water solution, 15-20 kg of harara is soaked in 20 litres of water. The fabric is dyed by keeping it in this mixed solution for 10 minutes, after which it is dried. In processing the second lot, four to five mugs of the harara-water solution is added, the cloth dyed in it for 10 minutes, and then dried. Thus the total quantity of the fabric is dyed in about ten lots, repeating the same process each time when dried, the fabric turns yellowish.

\section{Making of Colours}

The printing in Bagh is done with vegetable colours, derived from plants, fruits, flowers, and minerals. The only four basic (natural) colours: red, black, khaki, and indigo are being extensively used in this printing haven. The black colour is prepared with ferrous sulphate mixed with tamarind seed powder and glue, which is cooked in water and stored for use. The red is similarly produced from alum. In the case of grey, the printing is done with hirakayisha (earlier made of iron rust; now bought from the market) for developing the colour, the cloth is not boiled but is passed through a chalk solution/lime solution (chunekapaanikadhol). If a grey tone is being created, hehra powder 
[Chouhan et. al., Vol.7 (Iss.11SE): November 2019]

चित्रकला और उसके अंतः अनुशासनिक सम्बन्ध

Painting and Its Interdisciplinary Relation
ISSN- 2350-0530(O), ISSN- 2394-3629(P)

Index Copernicus Value (ICV 2018): 86.20

DOI: 10.5281/zenodo.3585086

is not used. It is when these colours are boiling with dhavda flowers and alizarine that the dramatic colours associated with Bagh prints are revealed. More colours - like blue, ochre and salmon pink - have also been introduced with the use of indigo and anaarkachilka (pomegranate skin). Other colours can be made, by using different natural commodities and by using differently the materials used in creating the four basic colours. Shades can be obtained by increasing or decreasing the material (colouring) used by varying the ratio of different material used. For example, increasing or reducing the quantity of hirakayisha, several shades can be created; alum can be varied to produce different shades of red. Any material like hirakayisha or alum has to be first made into a paint-like solution with imlikachiya (seed of the tamarind) to make a paint like solution. Hot water is added according to the required density of the paint/print solution. Generally, enough a colour is made once - in the morning - for the entire day's requirements. However, if needed, colours can be made any time. Alum is colourless - it produces red when boiled with alizarine and dhavdakaphool. Earlier, the root of the aal tree (aalkajad) was used as a fastening agent; now alizarine has taken its place. Alum absorbs colour on boiling with solutions made of colouring matter. The details of preparing the colours are as given below:

\section{Red Color Printing Paste}

$80-100$ gms. Fitkari (alum) is added to 1 liter of water and 20kg.alum 200liter water is taken. Black color printing paste Hirakasish or iron sulphate or iron filings are filled in earthen pot where jaggery and water are added to the pot and left aside for 15-20 days.

\section{Indigo Color}

An earthen pot is placed in a pit; a mixture of indigo leaves, lime and Sajji is then filled in the pot and left aside for 3 days. Paste thus formed is strained and used for dying. In present times, the indigo paste is prepared differently, Indigo powder / cake / granules are dissolved in water; caustic and hydro are added, to prepare the paste. The process of dying is same as of mustard. Indigo dyed fabric needs to be dried in shade otherwise the brightness of blue color changes.

\section{Khaki Color}

Leaves of Dhavdi are soaked in water and boiled for 10 to 12 hours and strained. The paste thus prepared is used for dying. The dying process is same as the Mustard. Mustard color: Pomegranate skins are boiled in water for 10 to 12 hours and strained. The fabric is then dipped in this hot solution. It is then removed and spread on stones for drying; this process is repeated for 3 times for final results.

Preparation of the color tray (palya): A wooden tray (earlier mud tray was used) with cement base is used for color tray. A bamboo mesh (kartali) is placed on the tray. A Mandan (small earthen pot) is placed under the tray for easy shifting of the balance of tray; the pot is placed with small stones for weight. A Chhombal / bhangarh (pot stand made of grass) is placed under the pot. A woolen mesh/blanket loosely woven is placed on the bamboo mesh. This arrangement in the tray is used for printing bold blocks. For fine block printing, a fine cloth of voile cotton is placed on the woolen blanket in the tray (pudath). The fabric is then taken up for printing.

\section{Printing}

The prepared paste as per required color is placed in the tray. The designed wooden block is placed in the tray; this helps to transfer the printing paste on to the block's raised portions. An impression 
of this is taken on the fabric with utmost care and precision, one block after the other and the complete fabric thus is printed. The entire printing process is detailed below: At this stage the cloth is meticulously and patiently printed by hand with the help of small design blocks. The designs are transferred very neatly on to the cloth. The time taken depends on the design and pattern, though, on an average about 5 metres can be printed by an expert worker in two to three hours. The fabric is printed upon using the hand-blocks. The fabric is dried before being folded. It is kept for a minimum of eight days and a maximum of two weeks for the colour to be absorbed properly by the fabric.

\section{Why We Call Ecofriendly Process Bagh Printing}

\section{Vegetable / Natural Dyes}

Historically of great importance, these dyes have acquired even greater importance now because of their eco-friendly nature. Bagru Black this is derived by mixing acidic solution of iron - often rusted nails/horse shoes etc. with jaggery (country sugar) allowed to rot for about 10-15 days. Many other natural substances used for producing dyes are pomegranate skins, bark of mango tree, vinegar, slaked lime etc. Bagru Red This dye is achieved by combining a source material such as alizarin with alum, the results ranging from pink to deep red.

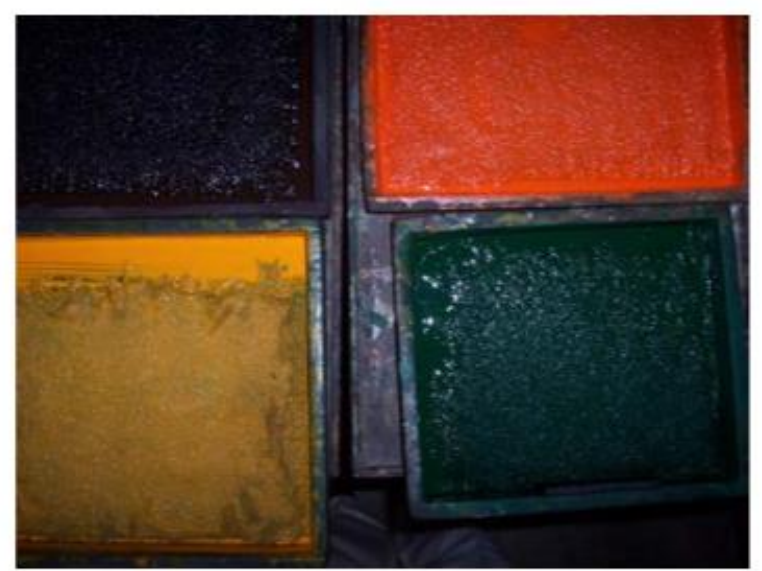

Figure 2: Eco-friendly nature colors

\section{Test Result of Sample}

\begin{tabular}{|l|l|l|}
\hline S.n. & Test name & Result \\
\hline 1 & caco3 & $384.2 \mathrm{mg} / \mathrm{l}$ \\
\hline 2 & ph $(25 \mathrm{dc})$ & 7.8 \\
\hline 3 & calcium carbonate & $83.2 \mathrm{mg} / \mathrm{l}$ \\
\hline
\end{tabular}

\section{Modern Trends}

Though the earlier Bagh prints were mainly used for ladies wear, however now apart from ladies wear an array of products made of Bagh prints are available in bed, pillow and table covers etc. The fabric used originally was cotton but now tassar, crepe and silk are being used. Though the technique and designs of Bagh print are age old, but the prints retain its contemporary appeal. It is 
even made on Bamboo chik, leather and jute products with natural colours. While the designs have been changed but the colours have been same. Today the traditional Bagh print faces stiff competition from chemical dyes which are available at a lower price. One such technique is Dabu block printing technique of Rajasthan. Dabu print is made from black mud, choona and gondh.

\section{Conclusion}

Bagh prints are friendly, cool and comfortable cloth material. Bagh layouts are dramatic with use of black and red alternately on a white background. The production process is painstaking and manual. Bagh prints are part of a tradition which has to be preserved for the future generations to take forward.

\section{References}

[1] http://www.straw.com

[2] india_resource@ tripod.com

[3] http://dhar.nic.in

[4] http://www.indianmirror.com

[5] A brief note on Bagh printing by Mohd. Yusuf Khatri, master craftsman, Bagh.

[6] Khanna Ruchika M. "Phulkari- making giving way to machine embroidery", Tribune News Service, Patiala, November, 12.

[7] Gupta Sonal, "Phulkari: The Art of Stitching", the Industrial Design Center (IDC), IIT Bombay.

[8] Naik, D. Shailaja, "Traditional Embroidery of India", A.P.H. Publishing corporation, 1996.

[9] Multiple Authors, "Asian Embroidery", Jasleen Dhamija, First published in India Craft Council of India, 2004.

[10] Art and Craft of Natural Dyeing, by I. N. Liles, Paperback UTN.

[11] Bechtold T., A. Mahmud-Alia and R. Mussaka. 2007. Natural dyes for textile dyeing: A comparison of methods to assess the quality of Canadian golden rod plant material. Dyes and Pigments, 75(2): 287-293.

[12] Chakraborty, May 11 (2009) Application of Eco Friendly Vegetable Dyes on Cotton Fabric.

[13] Frigerio, M. 1992. Natural dyes. Tinctoria, 89(12): 46-54.

[14] Gulrajani, M.L. and D. Gupta. 1992.

[15] Natural dyes and their application to textiles. Pp 81- 96. 6. M.P. Midday Editor (2011) Bagh Prints artists in Argentina for fourth Bharat Mahotsav.

[16] Pushpa Chari, Oct 20 (2011) written an article on Bagh prints. 